examined from their being covered with Tertiary strata or with drift and other superficial deposits.

These complex conditions renders the study of their origin a difficult one, but the key to their history is still to be found if facts are carefully noted, fossils collected, and their precise horizon and locality noted, and materials thrs accumulated for the comparison of the former physical and organic conditions of the Cretaceous sea of England with the faunas and physical aspect of the presumedly contemporary zones. Such a work has been ably commenced and carried on by many geologists, may their numbers be increased and the result is certain.

\title{
On a Section of the Lower London Tertiarieg at Park Hill, Croydon.
}

By H. M. KLAassen, F.G.S.

Park Hill Section, on the Woodside and South Croydon Railway, extends from the Upper Addiscombe Road, Croydon, to the footpath bridge near Coombe Road. Its length is 3,593 feet, of which 1,254 feet is tunnelled, as shown on the diagram (Fig. 2) by the letters $n-n$; and there are three cuttings, the south, central, and north.

In July, 1882, the Association examined the South Cutting. It was seen under most favourable circumstances: the weather had been dry for snme time, the Mottled Clay stood firm at an angle of $45^{\circ}$, having been dressed to the same slope as the underlying sandy beds, and the neatly trimmed banks displayed the variously coloured strata with such admirable definition that the divisions in the section were seen at a glance. A rainy season has since greatly altered the appearance of this cutting, and its brilliancy only exists as a pleasant remembrance to those who have seen it.

Before entering the cutting we observed, from the footpath bridge (at R., below S.S.W. in the section Fig. 2), on our right, the Oldhaven outliers of Addington Hills and Croham Hurst, covered with heath, gorse, broom, and firs, and we noticed that the railway at Park Hill cuts through a ridge which, shaped by denudation, lies between the Chalk and the London Clay. The highest point at Park Hill is 282 feet; its well-marked Tertiary escarpment orerlooks, 
Fra. 1.-General Shotyon wrom the Grystal Palace over Park Hifl to Oxted.

Crystax

PALACK.

N.

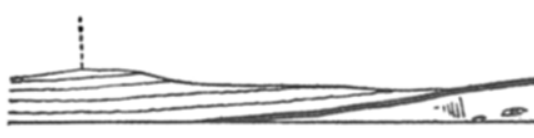

g

Horizontal Scale, 2 miles to 1 inch. Vertical Scale, 1,800 feet to 1 inch.

$a$, Weald Clay ; $b$, Lower Greensand; $c$, Gault ; $d$, Upper Greensand; $e$, Chalk ; $f$, Woolwich and Reading Beds ; $g$, London Clay.

Fig. 2.-Park Hill Section on the Woodside and South Croydon Railway.

$$
\text { Scale : }\left\{\begin{array}{l}
\text { Horizontal } 528 \text { feet }=1 \text { inch. } \\
\text { Vertical } 80 \text { feet }=1 \text { inch. }
\end{array}\right.
$$

N.N.E.

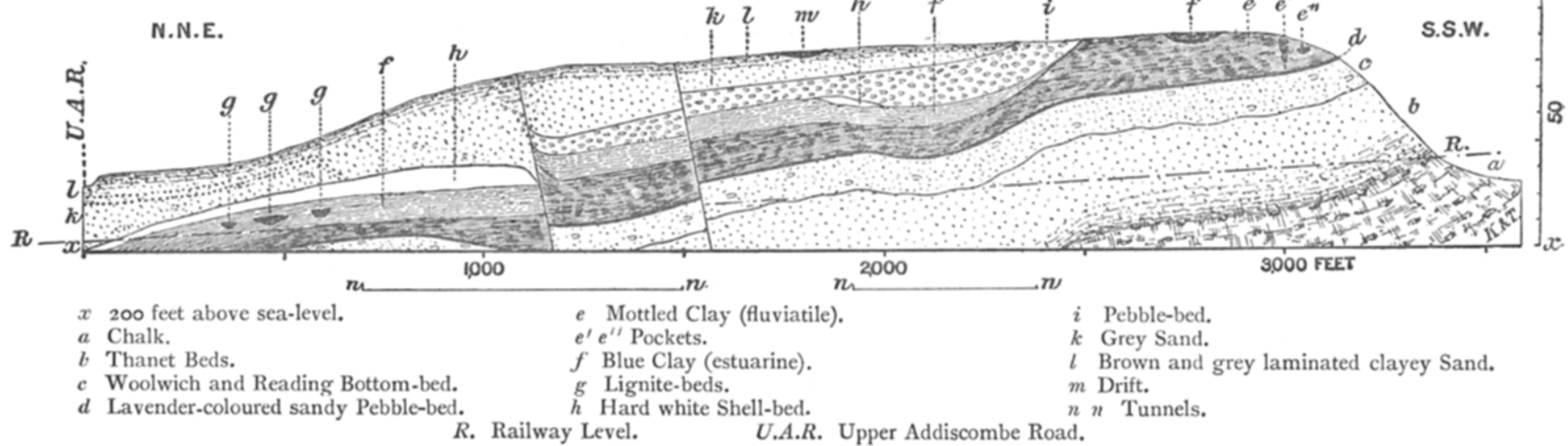


with a southward face, the dip-slope of the Clalk, which attains a height of 797 feet at Woldingham; and at Sydenham, three miles north of Park Hill, the London Clay is 367 feet above the sealevel.

From the footpath bridge we passed into the railway cutting and examined the Thanet Beds ( $b$, in Fig. 2), the lowest strata exposed. They are here a loose, incoherent mass of almost purely quartzose sands, and thoroughly pervious to rain, so that not much carbonate of lime has been retained. Not a shell, nor a fragment of a shell, was found, and ferruginous sandstones were also absent. Towards the base of the cutting there are iron-stained cylindrical casts of irregular tubes in horizontal positions, some of them filled with clay. The quartz grains in the upper portion are angular and sub-angular, and their thickness is much less than the length or breadth, as will be seen from the following measurements :-

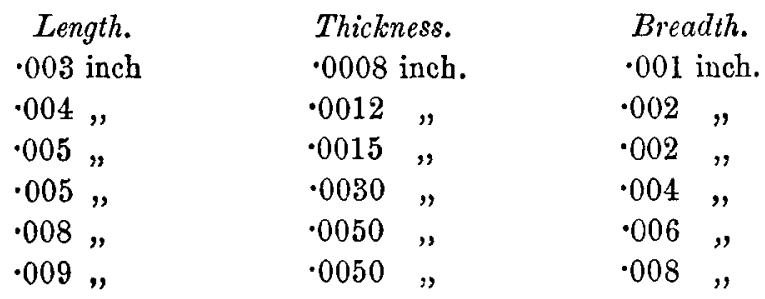

The angularity and the difference between length, thickness, and breadth, indicate that the sand was not rolled along, the particles being suspended in agitated water, and then spread by tidal action and marine currents. Most of the quartz grains are colourless and transparent, but a few are of different shades of yellow, orange and red, due to hydrated ferric oxide deposited on their surfaces. The colour disappears when they are boiled in bydrochloric acid. I have not found any crypto-crystalline silica indicating the presence of flint-particles. Quartz and flint are easily distinguished by the microscope, the former exlibiting the colonrs of polarisation, while flint remains grey. Besides angular and sub-angular quartz, there are a few grains of mica, grannles of oxide of iron, and green, dark-green, and black grains, with rounded ontlines, which crush into a fine amorphous powder. The npper portion of the Thanet Beds, when dry and seen from a distance, looks white. In the lower portion the quartz grains are sub-angular, 
and there is less difference in their length, breadth, and thickness. A greater percentage here is coloured, some of the red grains being very brilliant, and evenly stained over their surfaces. Mica is scarcer and green grains with rounded outlines are more abundant. This part of the bed, in which red patches and red veins, due to iron-staining, are frequent, has a light-buff appearance. The total thickness of the Thanct Beds, ascertained by boring down to the Chalk is 38 feet. The surface is eroded, and upon it lies the Wooluich and Reading Bottom-bed, (c, in Fig. 2).-The period of deep-sea deposit came to an end by a movement of elevation, from land thus raised, material was carried down, and 2 feet of brown, clayey sand, constituting the lowest division of the Bottom-bed, was spread over the Thanet Sand. Ostrea bellovacina lived and flourished along the coast; for its fossil shells are very abundant here, and are found in all stages of growth, up to 9 inches by 7 in size. They are in a good state of preservation and lie loose in the sand; to some Serpula are attached, others show borings of Cliona. A singular fact to be recorded is the extraordinary number of Shark's teeth found towards the base of the bed, including Lamna contortidens, Otodus obliquus, and a second form, without lateral cusps, which may be apiculatus of Agassiz (Vol. iii, number 32), not less than 700 teeth, mostly Lamne, having been collected by one gentleman. There were also found a Crocodilian tooth, one of an Edaphodont fish, fish vertebræ, Cardium, Nucula, Pholadomya, fragments of leaves, and some silicified stems of plants. A Perna, the first to be recorded as occurring in the Woolwich and Reading Beds of England, was found during our excursion in July by Mr. H. Turner, and is described at page 248, by Mr. E. T. Newton, F.G.S. This Perna will be presented to the Museum of Practical Geology, Jermyn Street.

The brown clayey sand contains here and there small black flint-pebbles, very smoothly worn, which are the representatives of Chalk flints long exposed to the wearing action of the sea ; but it is not possible that the original rough Chalk nodules could have been reduced to small flint-pebbles on such a bed as that whereon Ostrea bellovacina lived free and unattached. The fossil-shells of this Oyster have the valves still united, and show hardly a trace of injury. The pebbles, already rounded, were brought down and deposited simultaneously with the brown clayey sand.

Grey Sund.-The next division of the Woolwich and Reading 
Bottom-bed, 2 feet of grey sand, withont pebbles, contains grey nodules of sand cemented together by calcareous matter. From one of these nodules $\mathrm{Mr}$. W. H. Wicks obtained, during the excursion, part of a Crustacean, and at one of the meetings of the Association the claw of a lobster from this bed was exhibited.

Greenish-brown Sand.-The third division is 6 feet 8 inches of coarse greenish-brown sand. Veins of iron-staining run through this bed, and greenish-brown nodules occur, containing crustacean remains; borings of Mollusca are visible, the largest burrow noticed being 2 feet deep. Coloured flint-pebbles here make their appearance for the first time in the Woolwich and Reading Beds; they are well worn, irregularly ovoid and of a greenish-grey colour.

Green Sand.-The fourth division of the Bottom-bed is 3 feet of green sand with iron-stained veins. Its colour, a malachite green, made a striking contrast to the higher-lying mottled clay. Dr. Hodgkinson has kindly sent me an analysis of this sand, as follows :-

\section{Mean of three analyses.}

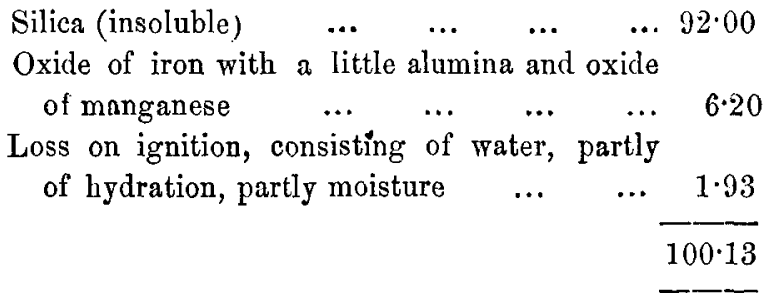

"These figures seem incorrect, but the substance contains iron in the lower state of oxidation, and thus gains weight on being heated in contact with air. The amounts of alumina and manganese are very small, and the figures in the analyses not quite reliable. The silica is present partly as quartz particles, partly as a silicate of ferrous oxide, or as glauconite. Calcium and magnesium are only present in very small amounts."

When examining this sand microscopically I was surprised to find how readily cold water washes ont the green colouring matter which settles as an amorphous deposit, leaving the water clear. The quartz grains are then seen to be transparent, with here and there a grain coloured red, yellow or green, and they are partly subangular, partly rounded. With regard to casts of Foraminifera, which green sands are supposed to contain, I must confess my 
inability to find them in this sand. There are some minute organisms, though obscure, a few rounded dark-green grains which crush into a fine amorphous powder, and globular accretions of the green particles; but I fail to recognise them as casts of Foraminifera. The mass of green sand, when fresh cut, is coherent and contains well-worn pebbles irregularly ovoid, yellow or olive-green. Their colour is not a mere stain on the surface of the black flint; for many are entirely coloured through, while some have a black spot left on the underside. I have broken several and found the colouring internally and externally to resemble that of the green-coated flints at the junction of the Eocene with the Chalk, but the dye is not so deep.

The fifth and last division of the Woolwich and Reading Bottom-bed is the Lavender-coloured sandy Pebble-bed ( $d$, in Fig. 2) having a uniform thickness of 1 foot 6 inches. Black flint-pebbles, of various sizes up to a maximum of 5 inches by $3 \frac{1}{2}$, lie imbedded in a lavender-coloured sand, many of the large pebbles having their major axes nearly vertical. At the top there is a thin, hard, ferruginous and carbonaceous layer-an iron-pan, brown or ochreous in colour, occasionally with dark ferruginous concentric veins; and to the underside of this pan small pebbles and flakes of pebbles are attached. The lavender-coloured sandy pebble-bed, when freshly cut, was the prominent object is the cuttings; the colour, intensified by the green sand below and the mottled clays above, and its ironpan, running evenly along its surface, sharply marking the bed. Its course could easily be followed, and thus it became possible to trace distinctly, even through the tunnels, the inclinations and faults which occur in these Woolwich and Reading Beds. Since the bed has been exposed to the air-now a year and a half-the colour has much faded.

The various divisions in the Bottom-bed maintain throughout a regular thickness and are well-marked and easily distingnished by their different colours. They are of marine origin-shore deposits along the Thanet sea.

Mottled Clay, (e, in Fig. 2).-Upon the lavender-coloured, sandy Pebble-bed rests the lowest fluviatile bed of the Woolwich and Reading Series. A considerable elevation had taken place far inland, and by some extensive river-action the Woolwich and Reading mottled clay, without pebbles or sand, was deposited. Its greatest thick- 
ness, 21 feet, is in the South Cutting; it thins away towards the North, and measures only 4 feet near the Upper Addiscombe Road (U.A.R., in Fig. 2). The colours of the clay are very brilliant; and a great length of it, seen together with the underlying Bottom-bed and the Thanet Sands, has an exceedingly attractive appearance.

At the base there is a layer, less than 1 inch thick, of compressed lignitic matter. An excellent opportunity for its examination has lately occurred. In order to check the instability of the slopes in the South Cutting, a width of 6 feet of mottled clay was cut off down to the lavender-coloured sandy Pebble-bed, the iron-pan of which was broken through, and a chalk wall, 3 feet thick, inserted to drain the water from above into the sandy beds below. Thus the base of the mottled clay was laid bare, and it was seen that the one inch of compressed lignitic matter extends, without interruption, along the whole length of the cutting. I have not been able to trace any structure in this deposit.

Upon the lignitic layer the mottled clays rest. They are moist and tenacious. The lowest 4 feet 7 inches, in which the predominating colour is mauve with greenish-blue and some ochreous patches, could be worked out by the pickaxe. The next 5 feet of clay, especially moist and tenacious, was blown down with gunpowder. The blasts left oblong cavities in the banks, and the large lumps blown out had smooth polished surfaces, resembling slickensides. This 5 feet of clay lies in large lamps, separated by vertical joints, and gives the impression of the material having been suddenly deposited by fits and starts, in big lumps. The narries spoke of the lumps as "having backs," an expression full of meaning to them in a mining or quarrying sense. This jointed structure made the working of the clay dangerous, the lumps unexpectedly sliding away to the right or to the left, and thus giving rise to accidents. The predominating colour is greenish blue, interspersed with patches, some mauve and a few ochreous. Here and there the colours intermingle. The next 4 feet was worked out by the pickaxe, its predominating colour being ochreous, with patches of greenish-blue, and some of mauve. Carbonate of lime has percolated here to a depth of 2 feet, and is deposited in streaks and nodules.

The uppermost part of the mottled clay for a thickness of $7 \mathrm{ft}$. 4in. is of a brilliant ochreous colour, with traces of mauve, 
but without greenish-blue. It contains calcareous matter which towards the base runs in wavy bands. At the point $e^{\prime}$ near the escarpment, the calcareons matter penetrates, in a pocket-like shape 18 feet wide at the top, the whole of the mottled clay down to the lavender-coloured band.

The mottled character of the clay is due to unequal oxidation and hydration of the iron and manganese. In the central portion of the bed which is especially moist and tenacions, greenish-blue is the prevailing colour; in the uppermost portion which is less moist and more exposed to the influence of weathering, ochreous colour predominates.

My best thanks are due to Dr. Hodgkinson, for the following analyses of the mottled clay :-

First rough analysis.- " $16 \%\left(\mathrm{Fe}_{2} \mathrm{O}_{3}+\mathrm{Mn}_{2} \mathrm{O}_{3}\right)$ in the form of ferrous and ferric oxides perfectly soluble in acids. There is about $10 \%$ of hydrated silica $\mathrm{Si}_{2}+\left(\mathrm{OH}_{2}\right)_{\mathrm{x}}$ but no sand. The hydrated silica was partly in combination with iron as well as with alumina. The quantity of calcium or lime is almost too small to estimate-much under $1 \%$. About $66^{\circ}$ of the clay is insoluble in acids, and consists presumably of aluminic silicate. This part of the analysis is now in progress, of which you shall have full details."

"The more detailed analysis has confirmed the rough results.

The sample of clay on drying at $100^{\circ} \mathrm{C}$ $\begin{array}{lllll}\text { lost water equal to } & \ldots & \ldots & \ldots & 6.36 \%\end{array}$ and on heating to redness a further $\quad \ldots \quad 7 \cdot 39$ being mostly water of bydration of the silica and alumina. The details are :-

$\begin{array}{llllll}\text { Total silica ... } & \ldots & \ldots & \ldots & \ldots & 47 \cdot 70\end{array}$

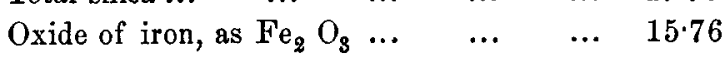

$\begin{array}{lllll}\text { Oxide of manganese } & \ldots & \ldots & \ldots & 0.12\end{array}$

Alumina, in the form of aluminic silicate... 23.36

\begin{tabular}{lllllr} 
& & & & $\overline{86.94}$ \\
Moisture $\ldots$ & $\ldots$ & $\ldots$ & $\ldots$ & $\ldots$ & 6.36 \\
Water of hydration & & $\ldots$ & $\ldots$ & $\ldots$ & 7.39 \\
\hline
\end{tabular}

In the mottled clay of the South Cutting, at point $e^{\prime \prime}$, there is a 
lens-shaped bed, 19 feet in length with greatest depth 2 feet, containing carbonaceous clays with numerous small crystals of selenite. The lower 4 inches of clay is reddish-brown and without plant-remains; the higher 1 foot 8 inches is dark-brown and contains fragments of leaves and other vegetable matter. The base of the lenticular bed stands above the compressed lignitic layer mentioned before and is separated from it by 1 foot 10 inches of olive-coloured clay which contains crystals of selenite. As this bed stands near the escarpment I have been careful to see whether it might be a lignite-bed of the blue Woolwich Clay; but this is not the case, as it is covered on the east bank by 4 feet and on the west bank by 10 feet of mottled clay. A piece of the darkbrown carbonaceous clay has been examined by Mr. J. Starkie Gardner, F.G.S., who has kindly sent the following remarks :-

"The hand-specimen, about 3lb. to 4lb. in weight, from the lens-shaped bed of clay, enclosed in mottled clay, consists of a highly laminated dark-brown carbonaceous clay, containing pellets of lignitised wood, small, flat, radiating crystals of selenite, and here and there a pale-yellow substance, the nature of which could only be determined by analysis. The presence of these extraneous matters in greater abundance, especially at the base of the specimen, prevents the clay from splitting so freely, but where they are relatively absent short laminæ of the thickness of wafers, may be lifted off. Though it abounds in vegetable matter, I am quite unable to detect any structure of value. There are undoubted traces of dicotyledonous leaves, and one fragment even presents a serrate margin; but they are so decomposed and macerated, evidently before they were embedded, that they afford not the slightest clue as to the kind of plants to which they might have belonged. The fine parallel venation of Rush or other waterloving plants predominates, and is occasionally very distinct. In only one case can I detect any distinct outline-that of a flat disclike seed, less than a quarter of an inch in diameter. Similar seeds, but larger, are found in the Reading Beds at Reading; but no conclusion, not eren the remotest, can be drawn from the vegetable remains as to the relative age of the bed. These results are disappointing, as at times it appeared as if some more complicated and characteristic venation could be traced out, but each time a re-examination has shown the futility of this.

"There are no Eoccne beds that I am acquainted with that 
compare in general appearance with it, except some of the so-called leaf-beds of the Bagshot Series of Whitecliff Bay, and some deposits between Rainham and Sittingbourne, on the Chatham and Dover Line. These latter I believe to be of about the same age, and they also contain the same form of selenite, the pale-yellow matter, and abundant vegetable remains in an identically macerated condition. They are rather paler in colour, and break into larger and more even slabs, but are equally disappointing; for, although they look at first sight as if they must abound in seeds and insect remains, I have never been able to extract anything distinct from them. It is, however, interesting to come across beds so identical in composition in such widely separated localities; and we have evidently to note for the first time a phase of deposition contemporaneous with that of the true mottled clay, but confined to the east of the London Basin. The geographical position, no less than the appearance and macerated condition of the regetation, leads to the inference that this quality of bed was deposited in tidal waters, either wholly fresh or brackish, while the fuller's-earth and mottled clay of Reading, which occupy the same horizon further up the old river-valley, have every appearance of being simply freshwater river-valley deposits. The contrast in the vegetable remains is very striking, and my observation has led me to believe that this peculiar kind of maceration can only result from prolonged flotation backwards and forwards in tidal water.

"The more natural position of this clay, supposing it to be a tidal deposit, would be below the mottled clay-that is, intermediate between the marine and freshwater series; but its position, as shown in the Park Hill Section, surmounted by mottled clay, is by no means opposed to the theory of its origin; for it would be absurd to contend that at no period and in no reach of a river could tidal and freshwater deposits intercalate. Its position, especially occurring at Croydon, supplies an almost unanswerable argument in favour of the view that this mottled clay and the laminated clay near Sittingbourne are contemporaneous.

"While examining this cutting, it has occurred to me as within the range of probability that the mottling process of these clays may have been due to prolonged saturation in sea-water subsequent to their deposition. I have always thought that they were originally of very similar character to the Lower Bagshot clays of 
Dorsetshire, and that a chemical re-arrangement has taisen place in them, which has doubtless destroyed their originally laminated structure, and all traces of their fossils. Identical mottled clays occur in the Middle-Bagshot at Bournemonth, and in the LowerBagshot along the borders of Dorset; and though a chemist must pronounce on the nature of the re-arrangement that has led to the mottling, I will take care to notice if these mottled clays have in all instances been directly exposed to the action of sea-water without the intervention of overlying clay-beds to intercept it."

When the Mottled Clay was first cut, fossils were not found in it. I can state this with certainty, as I have been a daily visitor at the railway during the whole period of its construction. On re-examining the South Cutting during the time the chalk wall was being put up along the base, I found at various heights Cyrence in the mottled clay. Geologists, who later on examine and describe this bed in Park Hill, may find the presence of Cyrence a stumbling-block; but the Woolwich blue Clay once overlaid the South Cutting; and an isolated piece of hard, calcareous, pale-blue clay and patches of Cyrence from this denuded bed were found lying upon the mottled clays when the cutting was first made. During the rainy season last year considerable landslips occurred in the South Cutting, which brought down the shells from above, and deposited them in the mottled clays.

The Woolwich and Reading blue Clay, ( $f$ in Fig. 2), resting upon the mottled clay in the Central and North Cuttings, has an even thickness of 10 feet, except for a length of 590 feet, to which further reference is made at page 245 . It has two principal divisions, well marked by fossil contents, and by the colouring of the beds. In the Central Cutting, the lower division or Cyrena-bed, 7 feet 2 incbes thick, consists of soft blue clay and hard bands of calcareous, pale-blue clay, from which the following fossils were collected:-Cyrena cuneiformis, Cyrena corlata, Nucula fragilis, Pectunculus Plumsteadiensis, Cerithium funatum, Melania inquinata, and Melanopsis buccinoides. The soft clay and the hard bands alternate, more or less in the following ascending order :-

Hard band of calcareous, pale-blue clay with

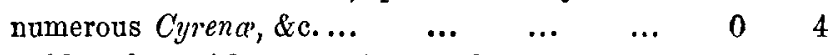

$\begin{array}{llllll}\text { Soft blue clay with some Cyrence, \&c. } & \ldots & \ldots & \ldots & 1 & 7\end{array}$

Hard band of calcareons, pale-blue clay with $\begin{array}{llllllll}\text { Cyrence, \&c. } & \ldots & \ldots & \ldots & \ldots & \ldots & 0 & 6\end{array}$ 
ft. in.

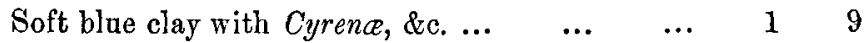

Hard band of Cyrence, cemented together in a

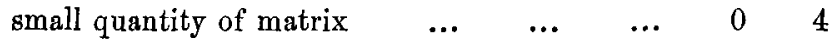

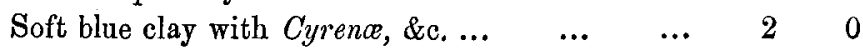

Hard band of calcareous pale-blue clay with $\begin{array}{lllllllll}\text { Cyrence, } \& \text { c. } & \ldots & \ldots & \ldots & \ldots & \ldots & 0 & 8\end{array}$

The shells are in a good state of preservation; some of the Cyrence stand with their siphonal extremity upwards, many have their valves united, and not unfrequently the brown epidermis is visible. A most diligent search on my part has failed to find Ostrea in this bed. A flattish spheroidal concretion, 2 feet 6 inches long, 1 foot 5 inches wide, and 7 inches thick, deserves mentioning. On being broken open it showed within Cyrena entirely covered with yellow crystals of calcic carbonate in scalenohedral form. The cavities within, and the hollow moulds of the Cyrence were coated with the same kind of crystals. The outer crust, 1 inch thick, consists of hard, calcareous, pale-blue clay. The lower division of the Woolwich blue clay in the Central Cutting is estuarine.

In the North Cutting there is a marked difference in the character of the bed; shells are fewer, hard bands of calcareous paleblue clay are absent; the clays are mostly soft and bluish-grey, and some are dark and carbonaceous; and lignite, Paludina, Planorbis, and remains of vertebrate animals are found. The whole has a distinctly fluviatile character.

The greatest portion of the soft clay is bluish-grey, and has a special interest on account of its plant-remains. Mr. J. Starkie Gardner, F.G.S., has carefully examined this bed, and gives a most interesting account in the following letter :-

"I have the pleasure of complying with your request that I should furnish some notes on the plant-remains found in the new railway-cutting at Croydon. So far as my observations go, they are confined to the 'blue Clays' belonging to the Woolwich Beds. The plant-remains are mainly more or less fragmentary leaves of Dicotyledons. Their condition is not very satisfactory from a palæontological point of view, though the leaf-substance itself is almost invariably preserved, and frequently may be peeled from the matrix of clay. The finer venation of leaves is far more difficult to trace when in this condition, than in the delicate impressions left by them in the paler clays of the Reading and Bagshot 
formations, and I have considerable misgivings as to whether it will eventually be found possible to determine more than a very small proportion of them. Owing, in fact, to the presence of pyrites in the clay, which renders the ultimate preservation of the specimens difficult, the fragmentary condition in which they have been collected, the absence of fruits, seeds, and other organs, and the obscurity of the secondary venation in nearly all, I am not sanguine that many can be figured in the 'British Eocene Flora' now in course of publication [Palæontographical Society]; yet, such as they are, they are of too great importance to be altogether passed over. I have seen but two specimens of Ferns among them; one a fragment collected some time since by $\mathrm{Mr}$. H. Turner, and a larger pinna, obtained in your company on the 25th of June. Both are portions of pinnæe torn from the palmate frond of Lygodium, with very fine sub-parallel venation set at an acute angle to the mid-rib. It is a sub-tropical form, which seems highly characteristic of the Woolwich Beds, for Professor Prestwich's collection contains many specimens from Counter Hill and Loam-pit Hill near Lewisham. It is essentially different from the better known Middle. Bagshot Lygodium of Bournemouth. I have also observed but a single Conifer, possibly a Cypress, with foliage similar to, but more delicate than that of Sequoia Couttsice of Bovey and Bonrnemouth. Among Monocotyledons there is the usual profusion, in places, of rush-like fragments, a hollow stem (filled with sand) with a thick carbonaceous integument in jour own collection, and pieces of a Fan-palm. The last I should have considered, from the associated character of the vegetation, to be a Palmetto, and I should judge it, as I have traced leaves in situ from the base to the extremity of the digits, to be not more than from 18 inches to $z$ feet in radius; but, as pieces of silicified palm-wood are said to have been found elsewhere in the Woolwich Beds, it may have been an arborescent form.

“The dicotyledonous leaves seem to be mainly evergreens, ovate or lanceolate in form, of small size, and with smooth or sliglitly serrate margins. I have seen a few fragments indicating leaves of larger size, equalling leaves of the Spanish Chestnut; but these also seem simple in form, and there is, so far, an apparent absence of anything like palmate, pinnate, or lobed leaves. On the whole, the flora appears to be highly distinctive, and confirms what I had previously only suspected, that the Woolwich flora is essen- 
tially different from the Reading flora; and I way add that it is the first time that I bave been able to collect personally from a bed of the former age, and consequently to form any definite conclusion on this subject.

"We are now aware of at least three distinct horizons in the Woolwich and Reading Series, from which plants bave been collected. The first is at the very base of the 'Mottled Clay' at Reading, and contains a flora of strikingly temperate aspect, principally characterised by leaves and fruit of the Plane tree and a supposed Poplar. I have already called attention to the fact that this flora is identical with some of the so called Miocene floras of Greenland. Although I have seen no distinct impressions of leares from this horizon in the Croydon cutting, I understand that you have found indistinct leaf-remains at the base of the mottled clays, resting on the lavender-coloured sandy Pebble-bed. *

"The second horizon is that of the 'blue clay' in the North Cutting, and is in all probability the same as that cut through many years since in the drainage works at Dulwich, a collection from which, made by the late Dr. Bowerbank, I have just reexamined. The discovery of this new horizon, with a sub-tropical flora, shows that the change in climate, from the temperate flora at the base of the 'Mottled Clay' to the tropical London Clay flora was gradual, and must to a great extent have taken place during the period of deposition of the 'Mottled Clay.' It also furnishes for the first time palæontological data, by which the Reading Bed period may be separated from the Woolwich Bed period. The small flora from Newhaven is valuable as furnishing some links between these two periods.

"The third horizon is represented, I believe, by the 'grey sands,' with clay partings and carbonaceous matter, above the 'hard white Shell-bed'; and I believe it will be found to correspond with the Loam-pit Hill and the Bromley leaf-beds. The evidence is as yet insufficient to show whether this last horizon contains any distinctive flora ; but it is remarkable that Plane-tree leaves and other lobed leaves recur in it, which so far seem absent in the 'blue clay' horizon.

"With regard to the origin of these beds, I think we are mostly agreed that the whole Woolwich and Reading Series represents the alternating estuarine and fluviatile conditions of a large

* See note subsequently written, above p. 234 . 
river. I regard the 'mottled class,' the 'blue clays,' and the 'grey sands,' as the three purely freshwater beds of the section, and the remainder as salt and brackish-water beds.

"From an attentive study of river-deposition, I consider the 'blue clays' to have been deposited in back-waters; for similar silts, crowded with leaves, are found in back-waters in many large rivers at the present day. The dark hrown, or nearly black, lenticular patches of so-called lignite imbedded in them must have been deposited when the back-waters were isolated, and had become stagnant ponds, gorged with decayed vegetation, and too free from foreign sediment for the leaves to have been covered np mitil all structure had rotted away. I believe that the present railwaycutting is transverse to the main direction* that these back-waters took, and consequently to the main course of the river of that period; and $I$ may add that $I$ saw no lignite in the cutting other than broken trunks of trees,"

Besides plant-remains, there were found in the soft bluish-grey clay Cyrena, Paludina, Planorbis, Hydrobia, Melanopsis, Melania ; scales, small teeth and rertebræ of fishes, and the rib of a turtle (Triony $x$ ). Since this paper was rend before the Association 1 have found some portions of large bones, which have been submitted to Mr. E. T. Newton, F.G.S., who pronounces them to be portions of a "gigantic bird" and intends, as soon as possible, to give a description of them. These, as well as the bones of the Coryphodon, mentioned later on, will be presented to the Jermyn Street Museum.

In the soft bluish-grey clay there are three basin-shaped beds, $g$, so called Lignite-beds. The clay of the one 84 feet long, with a greatest depth of 7 feet, lying 199 feet north of the tumnel, is dark-brown, contrasting strongly with its surroundings, and forming a conspicuous feature in the cutting, so that the whole ontline of the basin could be well seen from the banks above. Its outlines are defined by the soft bluish-grey clay along the basin-shaped part, and by a horizontal layer of brownish-grey clay above. This bed was examined during our second excursion in June, 1883. The sides along the slopes of the basin are lined with Cyrena caneiformis, Cyrena cordata, and Cyrena Duluichiensis, most of then well-preserved. At its base there is a 4-inch layer of com-

* The centre of the railway runs $30^{\circ}$ east of north, and the direction of dip of the blue clay in the North Cutting, to which Mr. Gardner refers, is $40^{\circ}$ west of north. 
minuted shells and fine calcareous sand. The clay is shaley, and contains Cyprida, Cyrena, Unio, Paludina, Hydrobia, Melania, and well-preserved Neritina globulus, showing the fine markings and colouring of the shell. When dry, the clay splits readily, and has a brownish tint. Prof. Rupert Jones, F.R.S., who has examined a piece of this clay, has kindly sent the following note:-

"On careful examination, I find numerous small Entomostracous valves and impressions on one plane of bedding. The little valves lie with their long axes roughly parallel, and in one general direction; they are delicately thin and white, some pearly and iridescent; but unfortunately they are either partially imbedded at their edges, as they lie with their convexity upwards, or are imperfect, when showing their interior. The best preserved individuals, however, present an outline similar to that of Candona Richardsoni, Jones ('Monogr. Tert. Entom.' Pal. Soc., 1856, p. 18, pl.4, fig. 12), and must be referred to that species, which has also been found at Woolwich and Lewisham."

In this basin-shaped bed I found some mammalian bones, which Mr. E. T. Newton, F.G.S., determined to be parts of the rare Lower Eocene mammal, Coryphodon, and which he has described at length in a separate paper (sce page 250 ). I qrote the following from one of his letters to me :-

"Considerable interest is attached to this discovery, inasmuch as it brings to light the most perfect ulna of Coryphodon hitherto obtained; and not only does it confirm the opinion that this creature is allied to the Tapirs, but, inasmuch as it shows by its articular surfaces that the radius must have been able to rotate to a considerable extent upon the ulna, it indicates a more generalised type of ungnlate mammal than any other known form. The Tapir has the radius firmly fixed to the ulna, and the ungulates, Palceotheriun and Anoplotherium, likewise had the radius and ulna immorably attached to each other."

The clay of the two other basin-shaped Lignite-beds is darkblue; they contain dicotyledonons leares, leaves of water plants, seed-vessels, pieces of trunks and stems of trees, also Cyrena, Paludina, Planorbis, Hydrobia and Melania. The leaves are in fairly good condition and their carbonaceots strbstance may be peeled off the clay in which they are embedded. The primary venation is often strongly marked, and the serrated edges are sharp and distinct. Some of the Sedgc-leares are thickly covered with 
Hydrobia and young Planorbis. The lignite, often charged with iron-pyrites, lies in seams following the curve of the bed, and from these I have seen navvies take out pieces of coniferous wood 2 feet long. The basin-shaped form of the Lignite-beds is due to the Woolwich blue Clay having been cut through transversely to the direction of the dip.

Above the Cyrena-bed in the North and Central Cuttings there is 2 feet 10 inches of soft brownish-grey clay, which forms here the upper division of the Woolwich and Reading blue Clay-the Ostrea-bed, in which Ostrea tenera and Ostrea bellovacina are most abundant. Between each layer of Oysters there is abont 8 inches of clay; the lumps of clay, when thrown down the enbankment, invariably splitting at the Oyster layer, leaving one valve of the shell on one part and the other valve on the other part of the divided lump.

There is evidence that the Woolwich and Reading blue Clay extended over the South Cutting. Cyrence lie scattered over the nottled clay, and on it also rests an isolated piece of hard calcareous pale-blue clay with Melanice and Cyrence, at $f$ near S.S.W. in the Section. The destruction of the shelly blue Clay may account for the calcareous matter which is deposited in streaks and nodules in the ochreous portion of the mottled clay, and has penetrated at the point $e^{\prime}$, near the escarpment, to the lavendercoloured sandy Pebble-bed. The blue clay at Park Hill is orerlaid partly by a shell-bed and partly by a pebble-bed.

The White Shell-bed ( $h$ in Fig. 2 ), consisting of shells of Ostrea, Cyrena, Melanopsis and Melania (most of them broken and comminuted), and of some carbonaceous fragments, is so hard that it was necessary to blast it. Small flint-pebbles, about half an inch in diameter, are embedded in its surface, and some few are found 8 inches below. At the junction with the overlying sandy bed in the North Cutting there are some tabular pieces of sandy limestone, 1 to 4 -feet long, about 6 inches thick, which split readily, and have within them Ostrea, Cyrena, and Melania. The white Shell-bed has a continuous length of 1,140 feet from Upper Addiscombe Road southwards. At U.A.R. (Fig. 2) it is 2 feet thick, gradually increasing towards the sonth, until half-way through the north tunnel the thickness is 10 feet. There it thins away to 6 feet, and from this height in a length of 26 feet to the fault it dies out with a sharp convex curve, which 
would be seen in a section drawn to an absolutely proportional scale. It appears to me that, previous to the displacement at the fault, this curvature formed part of the outline of the basinshaped pebble-bed which here came in. The position of the Pebble-bed at the fault was accidentally exposed. During the progress of tunnelling, the hard white Shell-hed supported the superincumbent mass; but on approaching from the North the thin end of the convex curve, a quantity of material from abore slipped into the tunnel-heading. It was seen that the Woolwich blue Clay occupied here a higher position than before, and that the Shellbed which had hitherto overlaid the blue Clay, was missing, and was replaced by 7 feet of the Pebble-bed (i, in Fig. 2), dipping in a southward direction, and above it lay 21 feet of grey and brown Sand, ( $k$ and $l$ in the Fig). A portion of the hard white Shell-bed, 160 feet long, and 2 feet thick, resting on the blue Clay, is met with again at $h$, about 2,000 feet from U.A.R., after an interruption of 680 feet.

The Pebble-bed, $i$, which I have now to describe, is basin-shaped, about 1,420 feet long, measuring in its greatest thickness 15 feet. It has not been possible to ascertain its extreme northern boundary; but it lies within 132 feet north of the convex ending of the Shell-bed just mentioned. There the sequence of the beds is exposed in a shaft, and is the same as in the North Cutting. Its southern boundary is above the mouth of the South Tunnel. The Pebble-bed is made up of-

I, a massive bed, i.e., smooth oval black flint-pebbles imbedded in various matrices, rendered more or less solid by a calcareous cement; and above this

II, a loose, incoherent, brown, calcareous sandy Pebble-bed.

1, The massive bed in its (1) lowest dipision consists of black fint-pebbles, angular pieces of shells, lignite, and carbonaceons fragments, imbedded in blue calcareous clayey sand. The pebbles have very often a pearly film of shell left by the Oysters which have been attached to them. At the base the bed is darker, more compact, and has numerous casts and moulds of Ostrea tenerca, Ostrea bellovacina, Cyrena cuneiformis, Cyrena cordata, Cardium, Melanopsis, Modiula, Calyptrcea, Cerithium funatum, and Melania inquinata. There are casts of ralves of Oyster-shells with a pearly film of the shell on the outside, and casts of Cyrence and Melanize attached to the inner side. This part of the bed con- 
tains fossiliferous pudding-stones, i.e., conglomerates of flint-pebbles, shells, casts of shells, and carbonaceous fragments in a calcareoarenaceous matrix, cemented together by a calcareous medium apparently derived from the shells themselves. The lowest division of the massive bed, in its greatest thickness 10 feet, lies north of where the Woolwich blue Clay has been hollowed out-from $i$ to $h$ in the Section.

The next division (2), thickness 1 foot 2 inches, consists of small flint-pebbles in brown clayey sand, with ferruginous lines and brown pudding-stones.

(3). Small pebbles in grey calcareous sand, ferruginons at base, 1 foot in thickness. This and the preceding division have angular fragments, and casts and impressions of various shells.

(4). Mostly small, but a few large pebbles in brown clayey sand, thickness 2 feet 2 inches, with casts and impressions of oystershells; at its base is a band of Ostrea, Pectunculus, and Cerithium, in a fair state of preservation.

The solidity of these beds gives them the appearance of being impervious to water, but I find, as the result of experiment, that the water slowly percolates. The massive bed is followed by

II, the loose, incoherent, brown, sandy Pebble-bed, occasionally compact and separated by a sandy layer from the previous bed. It contains whole shells, angular pieces, casts, and impressions of small Ostrea bellovacina, Cardium, Cyrena, Calyptrcea trochiformis, Pectunculus Plumsteadiensis, Panopaea intermedia, Modiola, Rostellaria and Cerithium funatum, and carbonaceous fragments and pieces of calcareous sandstones. At the top there is a sprinkling of very small flint-pebbles, but in the loose material there are pebbles up to 8 inches by 3 in size. During our excursion in June, 1883, I exhibited from this bed a flint-pebble with five large oyster-shells attached to it, the edges of which were rounded off. The casts and hollow moulds of shells in the compact mass are often covered with crystals of calcic carbonate. Polyzoa, one of which was determined by Mr. A. W. Waters to be Cribrilina radiata, are found on casts as well as on shells.

An inspection of the Pebble-bed, $i$, at once conveys the idea that the movement of the pebbles into their present position must have been gradual, for we have here whole sbells as well as shells with rounded edges, and angular fragments of shells. A sudden coming-in of the pebbly mass wonld bave ground the shells to powder. 
Besides this, the presence of pudding-stones implies gentle currents with intervals of quiet clearing of the water, conditions necessary to form conglomerates. The shells in the Pebble-bed are mostly of the same kind as those in the Shell-bed and in the Woolwich blue Clay, and it is possible that many of the broken shells in the Pebble-bed are derived from those beds. The isolated portion of hard white Shell-bed-160 feet long and 2 feet thick-at $h$, about half-way between the northern and southern boundaries of the Pebble-bed, may justify the conclusion that the Shell-bed, of which there is a continuous length of 1,140 feet in the North Cutting, once extended over the blue Clay in the Central Cutting, and was partly broken up by the incoming of the pebbles. The blue Clay itself, from $i$ to $h$, a length of 590 feet, has been denuded into the hollow occupied by the Pebble-bed.

On the western bank of the South Cutting, not visible in the section given at page 227 , there is a pebbly mass differing from the Pebble-bed just described. In this mass the pebbles lie in a loose brown sand, deroid of shells or shell-remains. About 3,000 feet to the east from here, and about 480 feet above sea level, are the Oldharen outliers, Addington Hills and Croham Hurst.

Grey Sand (k, in Fig. 2). Upon the hard white Shell-bed in the North Cutting, and upon the Pebble-bed in the Central Cutting, rests a loose grey sand, in greatest thickness 24 feet, with slight partings of impure pipe-clay, pellets of clay and thin layers of carbonaceous matter. The bedding is irregular, and the partings of clay, as in freshwater deposits, are not continuous. About 5 feet above the base of the bed there lie close together four brown clayey layers, the highest, 3 to 4 inches thick, containing carbonaceous fragments, and having at the top a thin iron-pan.

Brown and grey laminated clayey Sand (l, in Fig. 2), in greatest thickness 10 feet, moist and water-bearing, with ferruginous layers, lies over the grey sand. Near to the North Tunnel, at the base of the bed, where it begins to dip $1^{\circ} 50^{\prime}$ southwards, a dash of small flint-pebbles is found.

Angle and direction of dip, inclinations and faults. The long cuttings at Park Hill offered an opportunity of ascertaining with accuracy the angle and direction of dip of the Woolwich and Reading Beds there exposed. During the summer of 1882, when the neatly-trimmed banks in the South Cutting displayed the variously coloured strata to perfection, measurements were taken from the 
base of the Mottled Clay. The greatest length of one and the same inclination in the South Cutting is 540 feet, with an angle of $0^{\circ} 54^{\prime}$; the relative heights of the bed on the east and west bank make a slope of $2^{\circ} 33^{\prime}$ towards the west; the centre line of the railway runs $30^{\circ}$ east of north. From these data we find the full dip of the Mottled Clay here to be $2^{\circ} 42^{\prime}$, and its direction $40^{\circ} 34^{\prime}$ west of north.

As the course of the lavender-coloured sandy Pebble-bed has been traced thronghout the section, the various inclinations may be recorded. It crops out in the South Cutting near the escarpment at a height of 271.50 feet, and falls 66.20 feet northwards, i.e., $1^{\circ} 33^{\prime}$ in a distance of 2,445 feet, being there $205 \cdot 30$ feet above sea-level. The details of these inclinations are, from south to north-

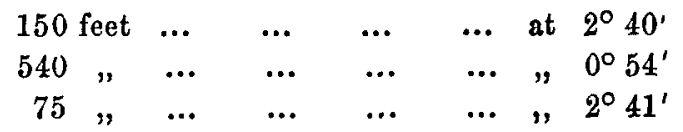

$$
\begin{aligned}
& 485 \text { "falling } 17 \text { feet } 6 \text { inches at } \\
& \text { various inclinations. forming } \\
& \text { an } S \text { curve. } \\
& \begin{array}{rccccccc}
320 & , & \ldots & \ldots & \ldots & \ldots & \text { at } 1^{\circ} 31^{\prime}{ }^{\prime} \\
33 & \prime & \ldots & \ldots & \ldots & \ldots & , \quad 4^{\circ} 28^{\prime} \\
4 & , 6 & \text { inches } & \ldots & \ldots & \ldots & , 33^{\circ} 40^{\prime} \\
170 & \prime & \ldots & \ldots & \ldots & \ldots & , \quad 3^{\circ} 26^{\prime}
\end{array}
\end{aligned}
$$

Here the lavender-colonred sandy Pebble-bed is $210 \cdot 80$ feet above sea-level; and so far the bed was exposed without interruption. At a point 225 feet farther north it was seen at 208.50 feet; and 443 feet farther north at $205 \cdot 30$ feet above the Ordnance datum.

In the reverse fault, shown in the section, the lavender-coloured sandy Pebble-bed is thrown down 3 feet in a distance of 4 feet 6 inches, making an angle of $33^{\circ} 40^{\prime}$ with the horizontal, or a hade of $56^{\circ} 20^{\prime}$, direction $3^{\circ}$ west of north. The hading is not in the direction of the downthrow.

Effects of Rainfall. After several months of superabundant rainfall (at Croydon, 16.365 inches from October to February inclusive), the aspect of the South Cutting was, in March, 1883, very different from that which it presented when visited by the Association in July, 1882. At that time the sides, dressed evenly to an angle of $45^{\circ}$, showed the stratification of the various beds of sand, pebbles, and clay, to the greatest advantage; but under the influ- 
ence of the heary rain, althongh the sand has remained comparatively undisturbed, the beds resting upon it have slipped everywhere, and clay, pebbles, and sand have mingled pell-mell in a mass of "slurry" at the bottom of the cutting, completely blocking the way, and giving rise to a series of ponds of water. A few days of rain washed the mottled clays along the slopes, covering the Thanet Sands below with a clayey liquid. Here the clay stopped for some time, and when dry weather set in, there was adherent to the sands, half-way down, a crust of clay, 6 inches thick. Successive rainfalls brought about sudden alterations; the mottled clays flowed in streams, forming small deltas below, and covering the line of rails with inaterial 4 to 9 feet in thickness; the banks above were widening, and the clays seeking their angle of rest. Near the mouth of the tunnel the width of the cutting at the surface, originally 135 feet, has already extended to 176 feet, and there can be little doubt that the angle of stability of the beds in question has by no means yet been attained, and that with a return of wet weather the movement will continue.

Instability of Beds. The Woolwich blue Clay in the North Cutting was the first of the beds which gave proof of instability. On the night of the 6th October, 1882, a length of 200 feet, 32 feet wide, slid forwards, carrying along the superincumbent beds and surface-ground, with hedge, wooden posts, and a cask of water undisturbed, but pushing the rails and sleepers aside. This incident will suffice to illustrate the strong downward movements from the slopes of cuttings. In the cutting itself, where the temporary rails rested upon the blue Clay, a constant upward movement was going on ; the side weight of the banks pressed on and against the soft clay below, and frequently lifted the railway 2 to 3 feet in the course of a few hours. The banks gave way, and many hundred cubic yards of the upper beds slipped down from time to time. It is beyond the scope of this paper to mention what means were used to check the instability of the beds.

In the Central Cutting, containing a variety of beds (sandy Bottom-bed, blue Clay, mottled Clay, Pebble-bed, grey and brown Sands), the movements are inconveniently frequent. Thus, on the 27th of August, 1882, a slip from above covered up part of the line and buried eight railway trucks. The Woolwich and Reading Beds have the reputation of being unstable, and they have fully maintained this character in the cuttings through Park Hill.

I must not conclude without expressing my thanks to Mr. George 
Throssel, engineer to Mr. J. Firbank, the contractor of the Woodside and So uth Croydon Railway, for the valuable assistance he has rendered me by furnishing data for the preparation of this paper.

For the convenience of the reader, a table showing the suceession and the thickness of the beds, is here appended :-

Vertical Section of the Lower London Tertiaries at Park Hill.

Greatest thickness.

\begin{tabular}{|c|c|c|c|c|c|c|}
\hline \multicolumn{7}{|c|}{ Greatest thickness. } \\
\hline Brown and grey laminate & d clayey & Sand & ... & $\ldots$ & 10 & \\
\hline Grey Sand ... & ... & ... & ... & $\ldots$ & 24 & \\
\hline Pebble-bed ... & ... & $\ldots$ & $\ldots$ & ... & 15 & \\
\hline Hard white Shell-bed & $\ldots$ & ... & $\ldots$ & $\ldots$ & 10 & \\
\hline Blue Clay with lignites & $\ldots$ & ... & $\ldots$ & $\ldots$ & 10 & \\
\hline Mottled Clay & $\ldots$ & $\ldots$ & $\ldots$ & $\ldots$ & 21 & \\
\hline Lavender-coloured sandy & Pebble- & bed & $1 \mathrm{ft} .6$ in & & & \\
\hline Green Sand ... & $\ldots$ & $\ldots$ & 3,0, & & & \\
\hline Greenish-brown Sand & ... & ... & $6,, 8$ & " & & \\
\hline Grey Sand ... $\quad$... & $\ldots$ & $\ldots$ & 2,0, & & & \\
\hline Brown clayey Sand ... & $\ldots$ & $\cdots$ & 2,0, & & & \\
\hline Thanet-beds... & .. & ... & $\cdots$ & $\cdots$ & 38 & 0 \\
\hline
\end{tabular}

Appendix вy E. T. Newton, F.G.S.

Note on new species of Perna from the Woolwich Beds,

One of the most interesting contributions to the fanna of the Lower Eocenes, which has resulted from the excavation of the railway-cutting at Park Hill, Croydon, is the large species of Ferna discovered by Mr. H. Turner, in the "Bottom-bed" of the Woolwich and Reading Series, and kindly lent to me for description. Portions of several specimens were obtained, but unfortunately all are more or less mutilated. The example giving the best idea of the form is the one figured, which is little more than an internal cast. The greatest length of this specimen, from the hinge to the ventral margin, is about six inches, and its greatest width four inches, while the thickest part is rather more than an inch and a half. The umbones are prominent and overhanging, the area below them being concave for nearly half the length of the shell. 
The hinge-line forms with the anterior side of the shell an angle somewhat greater than a right angle (about $95^{\circ}$ ). The ligament-pits are narrow, there being four ridges in a space of three-tenths of an inch. The greatest antero-posterior extent of the shell is at about two inches from the ventral margin. The lines of growth are distinctly marked upon the cast, and show that at an early period of growth the ventral region was narrower than the dorsal. The outer surface of the shell, as shown by some of the less perfect specimens, was roughened by the strongly imbricating lines of growth.

Fia. 3.-Perna Cboydonensis, E.T.N., from Park Hill.

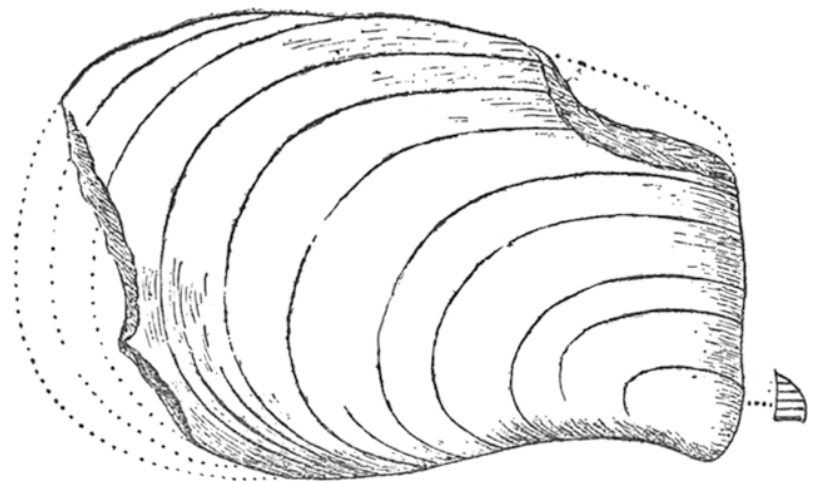

Hitherto no species of Perna has been recorded from the Lower Tertiaries of Britain, although M. Deshayes has described three from beds of approximately the same age, on the Continent, namely, Perna Lamarkii, from the "Sables moyens" of Valmondois, (Coq. Foss. p. 284, pl. xl, figs. 7 and 8); Perna aviculina, from the "Sables inférieurs" of Hérouval (Descrip. Anim. sans Vertébrés, \&c., 1864, p. 56, pl. 77, figs. 21, 22), and Perna Bazani, from the "Sables inférieurs" of La Hérelle près Saint-Just (ibid. p. 57, pl. 76, figs. 1, 2).

It is the latter shell which most nearly resembles the Croydon Perna; but it will be seen in $P$. Bazani that the angle formed by the hinge line with the front margin is much more acute, and this gives the shell an entirely different aspect, and prevents our referring the Croydon specimens to the same species. As it is desirable to give the new form a distinctive name, it is proposed to call it Perna Croydonensis. 